\title{
近代化遺産橋梁の保存決定要因に関する研究 \\ 一旧国鉄佐賀線・筑後川昇開橋を事例として -* \\ A Case Study on the Decision of Preservation of the Chikugo River Lift Bridge as an Industrial Heritage Bridge*
}

\author{
榎本碧 ${ }^{* *} \cdot$ 高尾忠志 ${ }^{* * *} \cdot$ 樋口明彦 ${ }^{* * * *}$ \\ By Midori ENOMOTO ${ }^{* *} \cdot$ Tadashi TAKAO ${ }^{* * *} \cdot$ Akihiko HIGUCHI $^{* * * *}$
}

\section{1. 研究の背景と目的}

近代化遺産橋梁 ${ }^{* 1}$ は、明治維新から第二次世界大戦 までに建設され、わが国の産業とその発展を支えた橋梁 で、旧碓水線の橋梁群のように重要文化財として指定さ れ、文化財として保存活用されている事例もある ${ }^{1)}$ 。また、 四谷見附橋の架替問題を契機に土木学会や文化庁により 全国的な近代化遺産の調査 ${ }^{2), 3)}$ が行われるなど、保存活 用に向けた取り組みが行われている。

しかし一方で、餘部鉄橋のように歴史的な価値を十分 に有する近代化遺産橋梁であっても、橋梁の劣化状況や 維持補修費の問題から撤去される例もある。このように、 近代化遺産橋梁は補修費の確保問題や道路・鉄道路線の 廃止などにより、撤去の対象となることがあり、その保 存に向けた方策の検討が求められている。そのためにこ れまで保存された事例について、その保存に至ったプロ セスを明らかにすることは重要である。

そこで本研究は、これまでに保存に至った事例として 筑後川昇開橋（以下、「昇開橋」とする）を対象（写真 -1、図 -1）に、その保存に至った要因を明らかにするこ とを目的とした。昇開橋は、撤去問題を機に、観光資源 として活用に向け地元住民による保存要望と保存のため の活動が行われ、実際に保存に至った橋梁であり、我が 国における先進的な事例として、本研究の対象とした。

\section{2. 既往研究}

近代化遺産橋梁の保存に関する既往研究は、保存事業 の報告を行ったものが多い。例えば小西らよる碓水線の 報告 ${ }^{4)}$ では、主に保存決定後の保全事業の調査を通じて

*キーワーズ : 景観、観光・余暇、土木史 **学生員、工修、九州大学大学院工学府

（福岡市西区元岡 744、ウエスト 2 号館 1104 号、

TEL 092-802-3392、FAX 092-802-3391、

E-MAIL:midori@civil.doc. kyushu-u. ac.jp)

***正員、工博、九州大学大学院

****正員、Doctor of Design、九州大学大学院

(TEL 092-802-3395、FAX 092-802-3391)
明らかになった構造物の技術的特長と、文化財としての 価值を示すとともに、事業の経過報告、構造物の現況・ 変状報告が述べられている。また、今らによる士瑺線の 保存に関する報告 ${ }^{5}$ )では、保存の経緯と構造物の技術 的特徵に加えて、近代化遺産の保存活用において市民や NP0の必要性について述べられている。

また、近代化遺産の保存活用プロセスに関する研究 は、安田らによる報告 ${ }^{6}{ }^{6}$ がある。この研究は保存活用が 良好に行われてきたと考えられる保存事例の管理主体に 対し、アンケート調查を実施し、プロセスと効果につい て分析を行っている。主な知見として、保存活用は(1)管 理者自身の発意、(2)取り壊しをきっかけとした保全要望、 (3)地域や専門家の自発的保全要望に基づくものに大別さ れること、また、保存活用事業は(1)近代化遺産の保全に 重点をおいているもの（文化的景観的価值を高める)、(2) 近代化遺産の保存を含めた様々な活用事業を実施してい るもの（地域活性化に資する）に大別される。そして保 存が決定された後、ボランティア活動、イベント開催、 関連施設整備は保存事業後に開始される傾向があること が述べられている。

また、昇開橋については、当時国内初であった可動形 式や浮船を用いた建設方法を紹介した報告等が数篇認め られる7。近年では、伊東による、わが国における可動

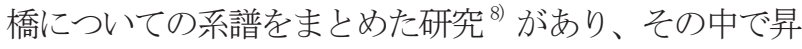
開橋の技術的意義に関して言及されている。

以上のように、既往研究は近代化遺産保存事業や橋梁 の価值評価について研究を行ったものが多く、保存決定 前の保存プロセスに言及した論文は管見の限り見受けら れない。

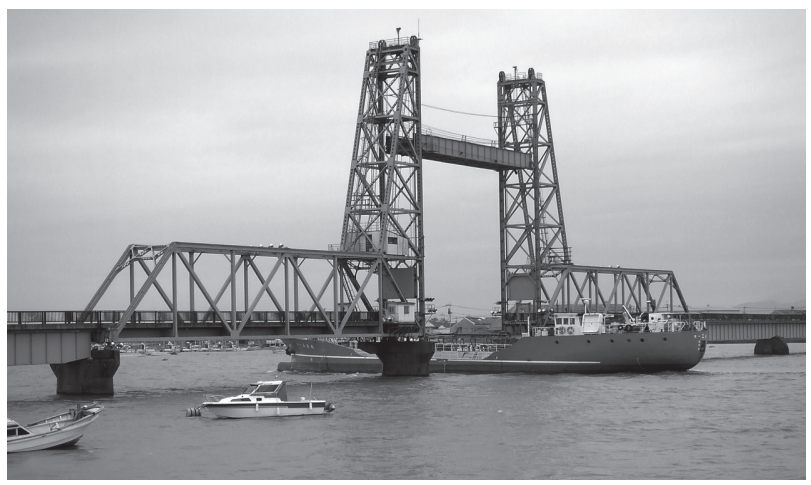

写真 -1 筑後川昇開橋（著者撮影） 
表 -1 筑後川昇開橋に関する文献（著者作成）

\begin{tabular}{|c|c|}
\hline \multicolumn{2}{|l|}{ 【行政資料】 } \\
\hline 筑後川昇開橋観光財団理事会資料 & 1996 年度 - 1999 年度, 2007 年度 \\
\hline 筑後川昇開橋観光財団資料 & 財団発足のための設立委員会資料 \\
\hline 佐賀線存続期成会総会資料 & 1987.6 .2 \\
\hline 地方特定交通線対策協議会会議録 & 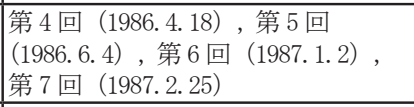 \\
\hline 旧筑後川橋梁保存管理活用計画 & $\begin{array}{l}\text { 大川市・諸富町・筑後川団資開橋観光 } \\
\end{array}$ \\
\hline \multicolumn{2}{|l|}{ 【団体資料】 } \\
\hline 若津振興会資料 & 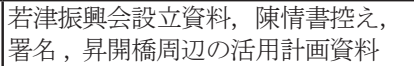 \\
\hline \multicolumn{2}{|l|}{ 【鄉土資料】 } \\
\hline 大川市誌 & 大川市誌編集委員会, 大川市，1977 \\
\hline 三潴郡誌 & $\begin{array}{l}\text { 福岡県三潴郡役所編，名著出版， } \\
1973\end{array}$ \\
\hline 新考三潴郡誌 & 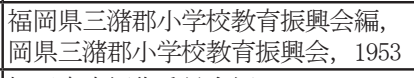 \\
\hline 柳川市史 & 柳川市史編集委員会編，1999-2006 \\
\hline 久留米市史 & 久留米市編， 久留米市, 1981-1996 \\
\hline 諸富町史 & $\begin{array}{l}\text { 諸富町史編纂委員会, 諸富町史編簤 } \\
\end{array}$ \\
\hline 筑後川五十年史 & $\begin{array}{l}\text { 建設省九州地方建設局筑後川工事事 } \\
\end{array}$ \\
\hline 筑後川歴史散策 & 国土交通省九州地方整備局筑後川工 \\
\hline \multicolumn{2}{|l|}{ 【学術関係】 } \\
\hline 土木学会誌 & 土木学会 \\
\hline 工事画報 & 工事畫報社, 土木学会監修 \\
\hline 橋梁と基礎 & 建設図書 \\
\hline 土木史研究委員会ニュースレター & 土木学会土木史研究委員会 \\
\hline \multicolumn{2}{|l|}{ 【新聞】 } \\
\hline 西日本新聞（福岡日日新聞） & $\begin{array}{l}1924 \text { 年 -2009 年,「筑後川昇開橋」「佐 } \\
\text { 賀線」関係主体等でキーワード梌 } \\
\text { 行い、そ後、実際の記事を参照 }\end{array}$ \\
\hline 佐賀新聞（佐賀日日新聞） & 同上 \\
\hline 読売新聞 & 同上 \\
\hline 朝日新聞 & 同上 \\
\hline 建設新聞 & 諸富町資料 \\
\hline 諸富新聞 & 諸富町資料 \\
\hline 日本経済新聞 & 諸富町資料 \\
\hline \multicolumn{2}{|l|}{ 【鄉土関係書籍】 } \\
\hline おおかわ文庫 $1-4 \% 2$ & おおかわ文庫編集委員会編 \\
\hline \multicolumn{2}{|l|}{ 【書籍】 } \\
\hline 九州鉄道の記憶 1-5 & 宇都宮照信，日本新聞社 \\
\hline 九州鉄道沿線案内 & 九州鉄道株式会社, 九州鉄道 \\
\hline 九州鉄道ものがたり & 桃坂豊, 弦書房 \\
\hline 九州の鉄道の歩み鉄道百年記念 & 日本国有鉄道九州総局 \\
\hline
\end{tabular}

\section{3. 研究の方法}

まず、昇開橋建設から現在までの経緯を整理した。そ の際表 -1 に挙げる昇開橋に関する文献、新聞記事、保存 に関する協議などの行政資料、郷土誌等を詳細に調査し た。

そして次に、保存決定の要因を明らかにするために、昇 開橋の保存の関係者であった行政職員、市民に対して聞 き取り調査を行った。当時の職員に話を聞くことが出来 なか力た大川市、日本国有鉄道（現独立行政法人鉄道建設・ 運輸施設整備支援機構）、建設省（現国土交通省）に関し ては、それぞれ現在の担当者から聞き取り調査を行った。 聞き取り調査の対象を表-2に示す。聞き取り調査は 2007

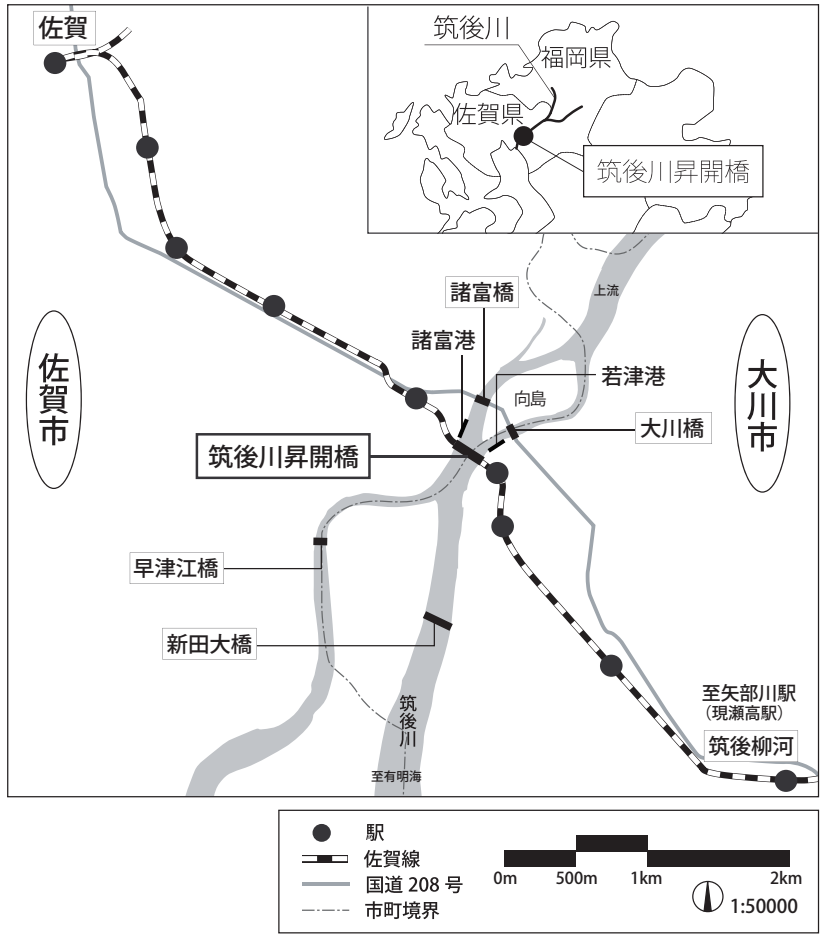

図 -1 筑後川昇開橋の位置（著者作成）

表 -2 ヒアリング対象者（著者作成）

\begin{tabular}{|l|l|l|}
\hline 大川市若津地区若津振興会 & 当時の事務局長 & 加藤貢氏 \\
\hline 佐賀市諸富支所 & 当時の担当職員 & 重松正博氏 \\
\hline 大川市生涯学習課 & ヒアリング時の担当職員 \\
\hline 財団法人筑後川昇開橋観光財団 & \multicolumn{1}{|c|}{$\begin{array}{l}\text { ヒアリング時の } \\
\text { 理長 }\end{array}$} & 龍博文氏 \\
\hline 国土交通省筑後川河川事務所 & ヒアリング時の担当職員 \\
\hline $\begin{array}{l}\text { 調査課 } \\
\text { 独立行政法人鉄道建設・運輸施設整 } \\
\text { 備支援機構 }\end{array}$ & ヒアリング時の担当職員 \\
\hline
\end{tabular}

表 -3 筑後川昇開橋の諸元 ${ }^{9)}$

\begin{tabular}{|c|l|}
\hline 所在地 & 福岡県大川市・佐賀市諸富町境 \\
\hline 橋長 & $507.2 \mathrm{~m}$ \\
\hline 幅員 & 可動部 $: 3.8 \mathrm{~m}$, 可動部以外 $: 2.5 \mathrm{~m}$ \\
\hline 建設 & 1935 年 (昭和 10 年) \\
\hline 佐賀線廃止 & 1987 年 (昭和 62 年 $)$ \\
\hline 移管 & 1992 年 (平成 4 年) \\
\hline 転用 & 歩行者道へ転用 \\
\hline 登録有形文化財 & 1996 年 (平成 8 年) \\
\hline 重要文化財指定 & 2003 年 (平成 15 年) \\
\hline
\end{tabular}

年 8 月、 2007 年 10 月、 2008 年 12 月の 3 回に分けて行った。

\section{4. 昇開橋の保存に向けた取り組みの経緯}

表 -3 に昇開橋の橋梁諸元を示寸。また、昇開橋の保存 の関係団体を表 -4 に示した。図-2には昇開橋の保存に関 して、1935（昭和 10）年の建設から 1996（平成 8）年まで の経緯を関係者別に示した。

\section{(1) 昇開橋の建設経緯}

昇開橋は日本国有鉄道（以下、「国鉄」とする）により、 筑後川下流を渡河寸る橋梁として ${ }^{10}$ ，1932（昭和 7）年 4 月より建設が開始され、1935（昭和 10）年 3 月に竣工し 
た ${ }^{11)}$ 。右岸側は佐賀県諸富町 (現佐賀県佐賀市)、左岸 側は福岡県大川市と $2 つ の$ 自治体に跨って架橋された。

大川市及び諸富町は、筑後川という大河に隣接してい たため、河川港の開発により水上交通が発達し、筑後川 には商業や漁業関係の船舶の往来が常にあった ${ }^{12)}$ 。図-1 に示寸ように、佐賀線の路線が若津港や諸富港の下流側 に計画されたため、上流の港に発着する船舶の往来を可 能にすることを目的に、昇開式の橋梁を建設することに なった ${ }^{13)}$ 。建設当時には、東洋一の規模の昇開橋であっ た ${ }^{14)}$ 。特に昇降部の規模が最大で、昇降部の可動システ ムも昇開橋のために開発されたものであった ${ }^{15)}$ 。

\section{（2）佐賀線廃止に伴う昇開橋の保存運動}

\section{a) 佐賀線廃止決定までの自治体の動き}

佐賀線は最盛期には最も乗降数が多い筑後大川駅で 1959 (昭和 34）年度に 1 日平均 1,103 人の乗客数があっ た ${ }^{16)}$ 。しかし、戦後、1955（昭和 30）年に筑後川を渡河 寸る道路橋（大川橋及び諸富橋）が完成し、国道 208 号 線が佐賀線と平行して整備されると ${ }^{17}$ 、鉄道利用が減少 し※3、1968（昭和 43）年9月には赤字線として国鉄によ る廃止路線案に含まれることとなった ${ }^{18)}$ 。

これを受けて同月に佐賀線沿線の 3 市 3 町（大川市、 諸富町、佐賀市、柳川市、瀬高町、三橋町）により国鉄 佐賀線存続期成会が発足し、佐賀線存続の要望・陳情が 国鉄、運輸省などに対して継続して行われた ${ }^{19)}$ 。また、 同年には諸富町議会議長等により国鉄佐賀線の廃止反対 に関する陳情書の提出も行われている ${ }^{20)}$ 。しかし、1980 (昭和 55) 年に日本国有鉄道経営再建促進特別措置法 (以 下、「国鉄再建法」とする）が制定されると ${ }^{21)} 、 1984$ (昭 和 59）年に第二次特定地方交通線として佐賀線は正式に 廃止認定を受けた ${ }^{19)}$ 。

廃止認定を受けると、1984（昭和59）年 7 月 22 日に国 鉄と沿線市町の代表、関係市町の警察との間で国鉄再建 法第 9 条で定めるところの特定地方交通対策協議会（以 下、「協議会」とする）が発足した ${ }^{22)}$ 。表一涝㬢会の 構成メンバー ${ }^{23)-26)}$ 、表一6に協議会の日程と協議の概要 27) を示す。

協議会では、表一6に示すように第 1 回から第 4 回まで は沿線市町村が主に路線の存続を求め話し合われていた が、路線の維持が困難であることが示され ${ }^{23)}$ 、沿線市町 が期成会で意見をまとめ、佐賀線廃止に同意すると ${ }^{28}$ 、 その後の協議会では廃止後の代替交通網としての道路整 備やバス路線整備などの対策や跡地払い下げなどについ て協議された ${ }^{24), 25)}$

1986（昭和 61）年 11 月 28 日に国鉄解体に関する法案 が成立し ${ }^{29}$ 、佐賀線はその後の 1987 (昭和 62) 年 2 月 26 日に行われた第 7 回協議会において廃止日が決定し ${ }^{26)}$ 同年 3 月 27 日廃止された ${ }^{30}$ 。
表 -4 昇開橋保存の関係団体の概要（著者作成）

\begin{tabular}{|c|c|}
\hline 国鉄清算事業団 & 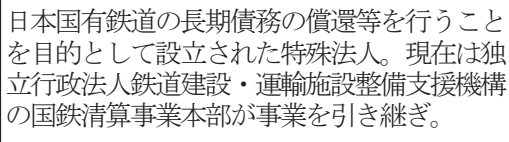 \\
\hline 大川市 & 昇開橋の現所有者。観光財団に出資。 \\
\hline 諸富町（現佐賀市） & 昇開橋の現所有者。観光財団に出資。 \\
\hline 国鉄佐賀線存続期成会 & $\begin{array}{l}\text { 昭和 } 43 \text { 年に廃止が発表されたことを受けて、 } \\
\text { 佐賀線の存続を目的に沿線市町 (大川市、柳 } \\
\text { 川市、三渚町、瀬高町、佐賀市、諸富町) に } \\
\text { より発足。昭和 } 62 \text { 年 } 6 \text { 月、佐賀線の廃止に } \\
\text { より解散。 }\end{array}$ \\
\hline $\begin{array}{l}\text { 特定地方線 } \\
\text { 交通対策協議会 }\end{array}$ & 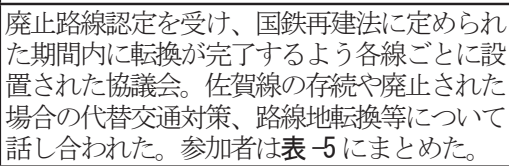 \\
\hline 若津振興会 & $\begin{array}{l}\text { 大川市若津地区住民を中心に作られた筑後川 } \\
\text { 昇開橋の保存を目的とした任意団体 }\end{array}$ \\
\hline 筑後川昇開橋保存会 & $\begin{array}{l}\text { 大川市長を会長とし、大川市側の住民、行政、議会によって作られた任意団体で、国県に保 } \\
\text { 存要望活動、昇開橋の再利用調査研究を目的 } \\
\text { としていた。 }\end{array}$ \\
\hline 筑後川貝囷圈法橋観光財団 & 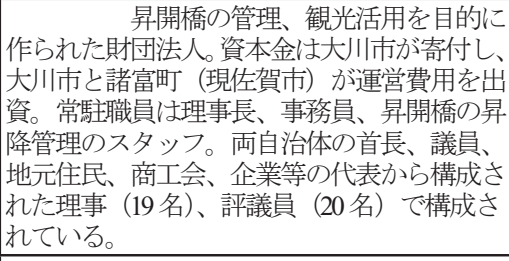 \\
\hline $\begin{array}{c}\text { 建設省 } \\
\text { 筑後川河川事務所 }\end{array}$ & $\begin{array}{l}\text { 筑後川の河川管理者であり、河川構造令に基 } \\
\text { ごき、河川域で改、撤去などの工事を行う } \\
\text { 場合、許可や指導をを行う。 }\end{array}$ \\
\hline
\end{tabular}

表 -5 特定地方交通対策協議会（著者作成） ${ }^{23)-26)}$

\begin{tabular}{|c|c|}
\hline \multicolumn{2}{|r|}{ 構成員 } \\
\hline 九州管区警察局 & 局長 \\
\hline 九州運輸局 & 局長, 企画部長 \\
\hline 九州地方建設局 & 局長, 佐賀国道工事事務所長, 事務所長 \\
\hline 福岡県 & 知事, 企画進行部長, 土木部長 \\
\hline 佐賀県 & 知事,企画開発室長, 土木部長 \\
\hline 福岡県警察本部 & 本部長, 交通部長 \\
\hline 佐賀県警察本部 & 本部長, 交通部長 \\
\hline 佐賀市 & 市長 $* 4$, 総務部長, 建設部長 \\
\hline 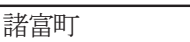 & 町長 ${ }^{* 4}$, 総務課長 ${ }^{* 4}$, , 建設課長 \\
\hline 大川市 & 市長 ${ }^{* 4}$,企画課長 ${ }^{* 4}$,都市計画課長 \\
\hline 柳川市 & 市長 ${ }^{* 4}$, 企画財政課長 *4, 建設課長 \\
\hline 三橋町 & 町長 ${ }^{* 4}$, 助役, 財政企画課長 ${ }^{* 4}$ \\
\hline 瀬高町 & 町長 ${ }^{4}$, , 企画開発課長 $* 4$,建設課長 \\
\hline 国鉄九州総局 & 総局長, 地方交通線部長 \\
\hline \multicolumn{2}{|c|}{ 参考人 } \\
\hline \multicolumn{2}{|c|}{ 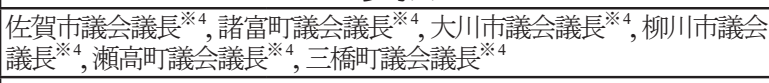 } \\
\hline \multicolumn{2}{|c|}{ 事務局 } \\
\hline 国鉄九州総局 & 地方交通線第一室長 \\
\hline
\end{tabular}

期成会は、佐賀線が廃止されたことで会の目的を失い、 同年 6 月 2 日をもって解散した ${ }^{31)}$ 。また、協議会は第 7 回を最終回とし、以後の協議は国鉄から国鉄清算事業団 (以下、「事業団」と寸る) へ引き継がれた ${ }^{26)}$ 。

b）国鉄による佐賀線廃止に伴う昇開橋撤去に向けた検討 諸富町で当時、昇開橋保存の担当職員だった重松氏一 のヒアリングでは「建設省から（河川占用許可期限切れ 


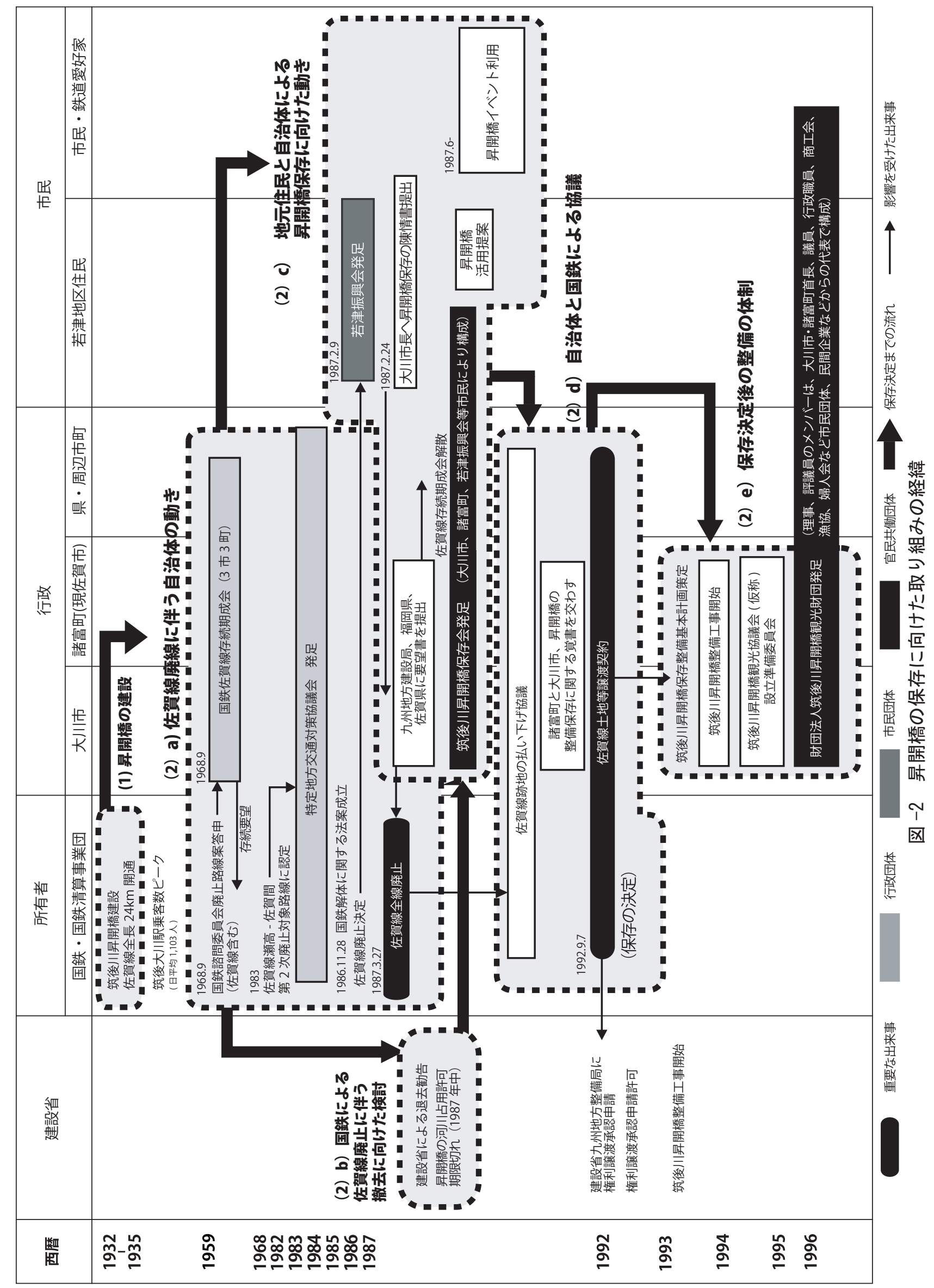


により）撤去の勧告が出され、国鉄でもその方で検討 された」と述べられている。また、当時の新聞において、 昇開橋は佐賀線廃止決定を受けて、河川工作物としての 占用許可の期限が 1987 年中に切れる予定であったこと がわかる ${ }^{32}$ 。 さらに、独立行政法人鉄道建設・運輸施設 整備支援機構の現在の担当職員へのヒアリングによると 「当時、撤去工事は国鉄清算事業団（以下、「清算事業団」 と寸る）が約 3 億円の費用をかけて行う予定となってい た」と述べられている。このように国鉄は昇開橋を鉄道 橋としての役目を終えた河川構造物として撤去する予定 にあったと考えられる。

\section{c）地元住民と自治体による昇開橋保存に向けた動き}

一方で、佐賀線廃止に向けて国鉄と自治体との間で 協議が進められていた 1987（昭和62）年1月に大川市 からの呼びかけで、大川市と諸富町の間で昇開橋の保 存について、打ち合わせが行われた ${ }^{33)}$

さらに、昇開橋撤去に向けた検討に伴い、大川市側 の橋の袂にある若津地区の会社経営者や商店主が中心 となって 1987 年 2 月 9 日に昇開橋の保存運動を目的と して若津振興会を発足し ${ }^{34)}$ 、同月 24 日に陳情書を大川 市長に提出するなど迅速に活動を開始した ${ }^{35)}$ 。

また、諸富町職員重松氏へのヒアリングでは「鉄道愛 好家から問い合わせや保存の要望の投書があった」と述 べられている。大川市側にも同様の投書があり ${ }^{36)}$ 、地元 住民や鉄道愛好家により保存を望む声があった。

また、期成会は建設省九州地方建設局および同大川支 所に昇開橋保存の要望書の提出を行った ${ }^{377}$ 。さらに、第 7 回の協議会において国鉄へ提出した要望書の中で昇開 橋の保存について述べられている ${ }^{26}$ 。

その後、同年 3 月 27 日に佐賀線が廃止になると、 4 月 9 日に大川市長を会長とする筑後川昇開橋保存会 (以下、 「保存会」とする）という任意団体が設立された ${ }^{38)}$ 。財 団法人筑後川昇開橋観光財団の現理事長の龍氏へのヒア リングによれば「保存会は若津地区住民、大川市、市議 会が一体となった団体で、活動内容は国県に保存要望活 動を行うことや再利用調查に向けた研究が目的であっ た」と述べられている。また、「保存会の設立当時は諸富 町側は関わっていなかったが、その後、大川市側から呼 びかけがあり、一体的に活動を行うこととなった」とも 述べられており、保存会は大川市が中心として設立した 団体であったと考えられる。

このように、佐賀線廃止に伴って地元住民により保存 を目指す団体として若津振興会が設立するなど保存運動 が起こった。また、大川市を中心とした自治体による保 存への動きがあった。その後は、住民と大川市が協力し、 大川市が呼びかけて発足した保存会が活動の中心となっ て国への保存要望が行われることになったと推察され る。
表 -6 特定地方線交通対策協議会の日程と協議内容 ${ }^{27}$

\begin{tabular}{|c|c|c|}
\hline 西暦 & 日付 & 協議会日程 \\
\hline 1980 & 12 月 27 日 & 国鉄再建法 \\
\hline 1984 & 6 月 22 日 & 佐賀線が第二次廃止対象路線に認定 \\
\hline \multirow[t]{2}{*}{1985} & 7 月 22 日 & 第 1 回 協議会等運営について \\
\hline & 11月 15 日 & 第 2 回 参考人出席について \\
\hline \multirow[t]{3}{*}{1986} & 1月 14 日 & \begin{tabular}{|l|l|} 
第 3 回 地方交通に関する諸問題について \\
\end{tabular} \\
\hline & 4月 18 日 & 第 4 回 佐賀線の運営内容見直しについて \\
\hline & 8 月 25 日 & 第 5 回 $\mid$ バス、第 3 セクターなど代替案について \\
\hline \multirow[t]{5}{*}{1987} & 1月 12 日 & 第 6 回 |バス案提示、バス転換承認 \\
\hline & $\begin{array}{l}2 \text { 月 } 20 \text { 日 } \\
2 \text { 月 } 21 \text { 日 }\end{array}$ & $\begin{array}{l}\text { 期成会が建設省九州地方建設局、福岡県、佐 } \\
\text { 県に要望書を提出 }\end{array}$ \\
\hline & 2 月 25 日 & $\begin{array}{l}\text { 期成会から国鉄九州総局長へ要望書の提出 } \\
\text { (代替交通の早期対策、昇開橋維持管理など) }\end{array}$ \\
\hline & 2 月 26 日 & \begin{tabular}{|l|l|} 
第 7 回 $\begin{array}{l}\text { 佐賀線廃止日の決定、代替バス転換 } \\
\text { 日の決定 }\end{array}$ \\
\end{tabular} \\
\hline & 3 月 27 日 & 佐賀線、筑後川昇開橋廃止 \\
\hline
\end{tabular}

\section{d）保存に向けた自治体と国鉄の協議}

昇開橋は佐賀線鉄道施設の一部であるため、昇開橋の 保存問題は大川市、諸富町と清算事業団との協議にお いて、佐賀線跡地利用の問題と一緒に議論されることと なった ${ }^{26)}$ 。観光財団の龍氏はヒアリングにおいて「協議 の際、(昇開橋の) 所有者の問題、線路や駅（昇開橋以外 の施設）の跡地利用などが問題になった」と述べている。 また、新聞記事からも清算事業団と自治体の協議は難航 していたことがわかる ${ }^{399}$ 。

このような問題の解決に向けて、保存を行う場合、大 川市と諸富町で共同管理者になるということが決定し、 その旨を国鉄に申し入れた ${ }^{40}$ 。また、昇開橋の整備保存 については、保存に必要な経費を両自治体で 2 分の 1 ず つとし、福岡県と佐賀県に財政支援の要請を行うことも 申し合わせた ${ }^{41}$ 。そして 1992 (平成 4) 年 9 月に、大川 市が清算事業団と佐賀線跡地の土地譲渡契約を結び、昇 開橋はその土地と共に変渡された工作物一式の一部に含 まれる形で大川市と諸富町の所有物となった ${ }^{22)} 。$

\section{e）保存決定後の整備の体制}

大川市と諸富町は、国鉄との協議と平行して 1991 (平 成 3）年に保存整備計画案を策定し ${ }^{43}$ 、昇開橋の維持管 理と活用を行う準備を行っていた。保存決定後、1993（平 成5）年から遊歩道整備事業が開始された。この整備は 1995 (平成 7) 年に終了し、1996（平成 8）年 4 月 29 日 から遊歩道として利用が開始された ${ }^{41)}$ 。

また、遊歩道の開通と同時に昇開橋の維持管理と観光 資源としての活用を目的に財団法人筑後川昇開橋観光財 団（以下、「観光財団」と寸る）が設立された ${ }^{45}$ 。この観 光財団は、保存会が母体となり、筑後川昇開橋観光協議 会（仮称）設立準備委員会を経て財団法人となった団体 で、メンバーには大川市長、諸富町長、地元住民などが 理事や評議員として参加している ${ }^{46)}$ 。観光財団龍氏への ヒアリングでは「(観光財団の) 資本金は当初、大川市が 国鉄から払い下げを受ける土地のために用意した約 3 億 円が充てられた」と述べられている。また、この観光財 
団の運営費はｉ）大川市之諸富町から年 550 万円ずつ出 資、ii）前述の資本金を預金した利息、iii）賛助会員の 会員費、iv ) はがき、写真集などの売り上げの他に不定 期の寄付金、補助金などによって賄われている。このほ とんどは毎年のメンテナンスや橋梁部品の交換など補修 費用の積み立てに用いられ、これら運営費の総額は平成 19 年度の収支計算書によると、16,067, 193 円となってい る。この運営費のほとんどは毎年のメンテナンスや数年 おきに行われる橋梁部品の交換など補修費用の積み立て に用いられ、その他はイベント運営費用などに充てられ ている ${ }^{47}$ 。

その後、昇開橋は、1996（平成 8) 年に有形文化財とし て登録され ${ }^{48}$ 、ささらに、2003（平成 15）年に重要文化財 に指定された ${ }^{49)}$ 。

\section{5. 保存決定の要因}

前章の昇開橋の保存経緯を踏まえて、昇開橋の保存決 定要因を抽出したものを以下に述べる。

\section{（1）地域におけるシンボル性}

\section{a) 昇開橋の認知度}

昇開橋は筑後川下流域で最初に筑後川を跨ぐ橋梁とし て建設されたことから、建設当初から地域住民にとって 印象深い橋梁であり、昇開橋の価值を地域住民が認知し、 愛着や誇りを持っていたと考えられる。

保存運動時の地元住民の声では「筑後川の風物」と評 されている ${ }^{50)}$ 。また、大川風土記の大川の名所旧蹟散歩 マップでも、昇開橋を散歩ルートに入れて紹介している ${ }^{51)}$ 。名称も「筑後川昇開橋」筑後川若津橋梁」「諸富鉄橋」「諸 富昇降橋」 ${ }^{* 4}$ など地域によって異なる表記が用いられて いた経緯があり ${ }^{52)}$ 、それぞれの地域で固有の愛称があっ たことがわかる。

また地域外でも建設当時、東洋一の昇降式可動橋とし てパリの万博に模型が出品されるなど ${ }^{14)}$ 、国内や世界の 目から見ても希少性のある橋梁であった。さらに、休み の日には鉄道愛好家が写真を撮影にやって来るなど ${ }^{33)}$ 、 地域外の住民にもその価值が認知されていた。特に当時 は、日本国有鉄道の民営化と赤字ローカル線の廃止とい う全国的な鉄道への関心があった ${ }^{54}$ と見られ、佐賀線で も廃止に向けて地域住民や鉄道ファンに向けたイベント が行われていた ${ }^{55)}$ 。諸富町職員重松氏へのヒアリングで は「鉄道愛好家から投書が届いた」と述べられている。

このように鉄道愛好家の声も市民に昇開橋への関心の 目を向けさせたと考えられる。

\section{b）商業地区住民による保存運動}

昇開橋の保存は、a）に述べたようにその価值を認めた 住民が存在したことだけではなく、そうした認識を持っ
た住民が、実際の保存活動として大川市では署名活動や 要望書提出、昇開橋活用計画の提案が行われ、諸富町で は行政へ保存要望の投書やお別れイベントを開催したこ とで、世論を形成し、自治体が国鉄に保存要望を行う際 の後押しとなったと考えられる。

要望書の提出や昇開橋活用計画を提案したのは、大川 市若津地区において昇開橋の保存とその活用により地域 を活性化させることを目的に発足した若津振興会という 団体であった。保存活動を行っていた当時、若津振興会 事務局長として活動していた加藤氏へのヒアリングでは 「とにかく昇開橋を残して観光の目玉にし、橋周辺の再開 発をしたかった」とある。この昇開橋活用計画では、昇 開橋にミニSLを通したり、イタリア村を作り昇開橋の周 辺を再開発することなどが提案された ${ }^{56)}$ 。このことから 以前は河川港のある商業町として隆盛を誇っていた若津 地区において、保存運動当時、衰退していた町の賑わい を取り戻そうとする若津地区住民の意思が保存運動への 大きな原動力となったことがわかる。

一方、諸富町側では、諸富町職員重松氏に対するヒア リングにおいて「諸富町の住民は漁師が多く、若津振興 会の立ち上げた保存の動きに協力したり、積極的な保存 活動を行うことはなかった。廃止直後はそうした活動が あったことも知らなかった」と述べられている。しかし、 昇開橋を活用した動きや撤去を惜しむ声として、諸富漁 協による橋の下をくぐったり、昇開橋の撮影会を行う遊 覧イベント ${ }^{577}$ や、諸富町の若者による昇開橋をバックに した音楽祭が向島（昇開橋が正面に見える筑後川の中洲） で企画される ${ }^{58)}$ など、まとまった活動はなかったが個別 の活動がなされていた。

新聞で行われた昇開橋の保存に関するアンケートでも 「今は無き国鉄の財産として保存すべき」などの保存賛 成の意見が高かったとある。また、反対意見の場合も撤 去を望むというよりは「老朽化が問題」という声が上がっ

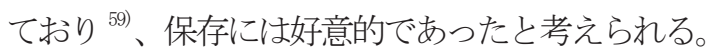

\section{c）観光振興に向けた自治体の動き}

自治体も廃止以前から地域シンボルとして昇開橋を観 光の目玉として指定し、活用を目指していたことから保 存に対して積極的であったと考えられる。当時の社会的 背景として、ふるさと創生事業などに代表されるように 特に全国的にまちおこし、村おこしといった地域資産の 掘り起こしや、イベント誘致などを行うなど活発な取組 みが行われていた。大川市の現職員に対するヒアリング では、「大川市と諸富町も周辺市町村と連携した観光ネッ トワークづくりを行うにあたって、一つの自治体に一つ の観光の目玉を設定するという取組みが行われていた。 そこで、大川市か諸富町のどちらかから昇開橋をあげる こととなり、結果として諸富町から昇開橋が取り上げら れた」と述べられている。また、佐賀線廃止以前より大 
川市の観光パンフレットの表紙に昇開橋が採用されてい る ${ }^{60)}$ 。このように、保存運動が行われる前から、自治体 でも地域の観光資源として昇開橋を認識していたことが わかる。このことから住民からの昇開橋の保存要望をす ぐに受け入れる土台があったと考えられる。

また、大川市長が積極的であったことが、保存を協議 する際に影響したと考えられる。大川市長は、期成会が 発足した 1968 年から佐賀線の廃止、昇開橋の保存が決 定寸る 1992 年までに中村太次郎（1966 年 5 月〜 1976 年 5 月)、古賀龍生(1976 年 5 月～1984 年 5 月)、中村晃生(1984 年 5 月～1989 年 6 月)、山崎健 (1989年 7 月〜 1993 年 7 月) の 4 人が務めている ${ }^{61)-64)}$ 。特に佐賀線廃止の議論が高 まった時期に市長を務めていた中村晃生は、佐賀線廃止 に関する協議にはじまり、保存会の発足の呼びかけや保 存会会長も務めた ${ }^{41}$ 。次の山崎健は、保存会を引き継ぎ 会長になると清算事業団との協議で昇開橋の保存につい て議論し、保存が決定寸ると保存会を財団法人化し、昇 開橋の管理体制を整えた。このように市長の交代があっ ても、それぞれが佐賀線跡地問題を含めた昇開橋保存に 関して一貫して関わっていた。このことから昇開橋の保 存運動は特に周辺住民による強い要望があり、保存運動 により世論が形成された上で、具体的な協議の段階に移 ると大川市と諸富町などの自治体が積極的であったこと が保存決定の要因の一つであったと考えられる。

\section{（2）交通機能の維持}

筑後川下流域は河幅が 500m で橋が少なく、昇開橋は、 立地上、歩道橋としての利用転換の要望もあった ${ }^{65}$ 。こ れは、図-1に示寸通り、昇開橋の周囲には $300 \mathrm{~m}$ 上流に 大川橋と諸富橋、 $1500 \mathrm{~m}$ 下流に新田大橋と早津江橋があ るのみで、歩行者にとって筑後川を渡河することは難し い状況にあったことが要因であると考えられる。

また、佐賀線廃止に伴い、昇開橋は鉄道橋としての 役割を終了したために、国土交通省筑後川事務所の現 在の職員へのヒアリングでは「(一般的に河川管理者の 見地から）使わないで単に保存することは問題がある」 と述べられている。しかし一方で「一度撤去するとも う一度橋梁を建設することは難しいことから、地域住 民の要望もあるため、よほど近接して橋梁が建設され たり、治水上重大な問題が発生しない限りは、過去の 例にあるように、管理を行うという前提で、そのまま の利用を許可寸る場合がある」とも述べられている。 このことから河川管理上、利用目的のない構造物は直 ちに撤去しなければならないが、昇開橋を歩道橋とし て利用することで継続利用の許可が下りたと推察され る。

このように、昇開橋が橋梁として交通機能を維持して いたことが河川構造物として継続して利用許可を与える
表 -7 保存に必要な費用の財源 ${ }^{47)}$

\begin{tabular}{|c|c|}
\hline 保存に必要な費用 & 主な財源 \\
\hline $\begin{array}{c}\text { 災害など } \\
\text { 有事の際の } \\
\text { 撤去費用 }\end{array}$ & $\begin{array}{l}\text { (1)大川市の佐賀線跡地の買取費用 : } 351,578 \text { 千円 } \\
\text { (筑後川昇開橋観光財団の基本財産として寄付) }\end{array}$ \\
\hline $\begin{array}{c}\text { 定期的な } \\
\text { 維持管理費用 } \\
\text { (財団運営費から積立) }\end{array}$ & 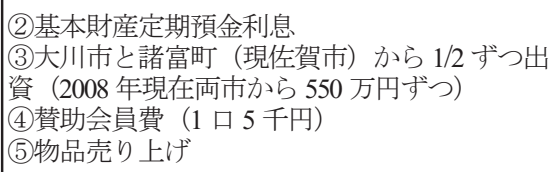 \\
\hline $\begin{array}{l}\text { 活用に向けた } \\
\text { 整備費用 }\end{array}$ & $\begin{array}{l}\text { (6)地域総合整備事業債、宝くじ助成 } \\
\text { (ただし自治体による地方債の発行、助成申請) }\end{array}$ \\
\hline
\end{tabular}

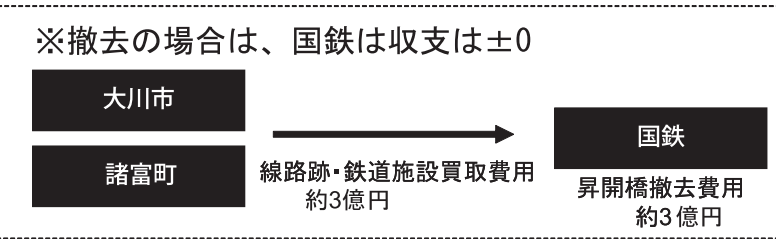

保存に向けて

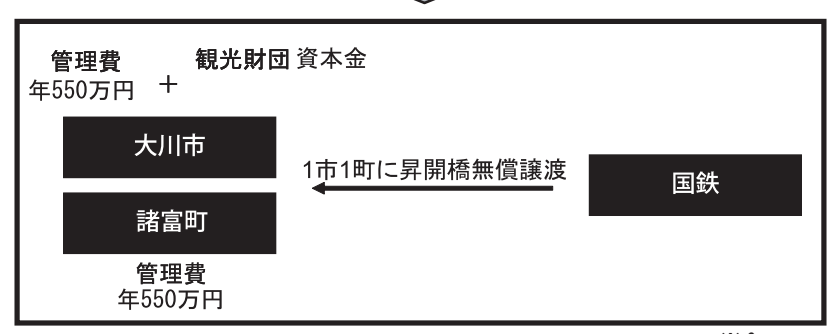

図 -3＼cjkstart国鉄との協議における費用の収支 $* 6$

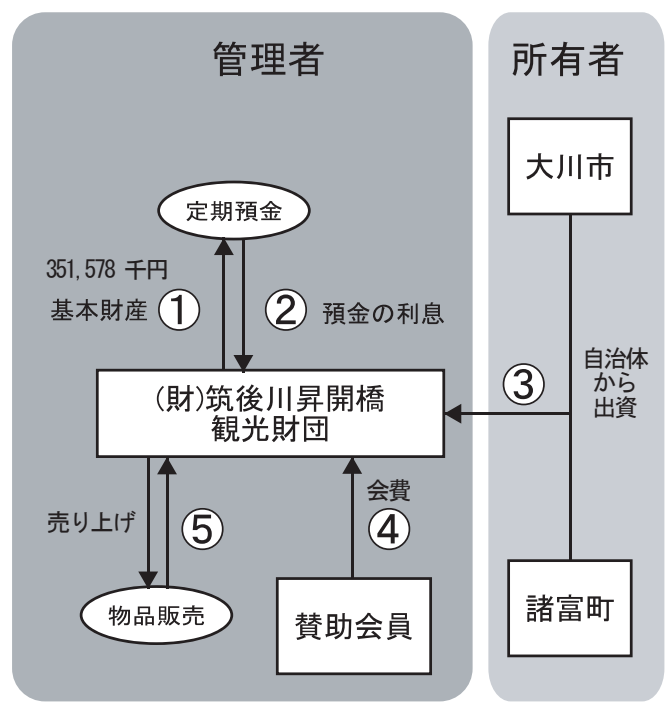

図 -4 財団の運営費用の流れ（番号は表 -4 に対応）

根拠となり、保存の要因の一つとなったと考えられる。

\section{（3）保存に必要な財源の確保}

\section{a）昇開橋の保存に必要な費用}

昇開橋の保存には、災害などの有事の際の撤去費用、 維持管理費用、整備費用が必要であったと考えられる。 表-7に保存に必要な費用とその財源についてまとめた。 
それぞれの費用について見ると、まず撤去費用につい ては、河川法令上、河川構造物である昇開橋を有事の際 にすぐさま撤去を行うことを担保する費用であり、管理 者としての責任の所在を示寸意味で必要であった ${ }^{66}$ 。維 持管理費用についても同様に、管理者として構造物を良 好な状態に維持するという意味で定期的な財源を確保す る必要があった ${ }^{33)}$ 。また、整備費用については、橋梁の 状態は良好であり、すぐに大きな補修が必要ではなく、 保存にかかる費用としては抑えられたが、鉄道橋として の供用時は床版や高欄が無いために、歩道橋として整備 する費用が必要であった ${ }^{67}$ 。

\section{b）撤去費用}

4. (2) に示したように、撤去を行う場合の費用は約 3 億 円程度と概算されていた。図-3に示すように、この金 額が大川市の佐賀線跡地の評価額と同程度であり、その 土地代と昇開橋の撤去費用を相殺し、国鉄が大川市に佐 賀線跡地とともに昇開橋を譲渡する形で保存が決定した

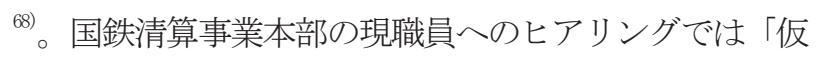
に撤去が決まった場合でも地元の漁師らとの漁業権に関 する話し合いが改めて必要になった」と述べられている。 このことから当時の国鉄清算事業団の性質上、撤去費用 を確保することも難しかったと推察される。

また、佐賀線跡地を国鉄から大川市へ䇏渡寸る形にし たことで、4. (2)e) で述べたように、大川市が佐賀線跡 地買取のために用意していた財源を撤去費用として充足 し、有事の際の管理責任を示すことができた。

このように、最終的に保存を行う場合、前管理者の国 鉄清算事業団の負担が撤去する場合よりも軽くなったこ と、そして佐賀線跡地の買取費用を無償とすることで、 その費用を昇開橋の撤去費用として確保できたことが保 存を決定した要因であったと考えられる。

\section{c）維持管理費用}

大川市と諸富町は昇開橋の維持管理は財団法人筑後川 昇開橋観光財団を設立し、管理を委託することで、継続 的な管理を行うとしている ${ }^{46)}$ 。観光財団の運営費の流れ を図-4に示す。4. (2)e) で述べたように、昇開橋の維持 管理費用は財団の運営費の中から主に(2)基本財産の預金 の利息と(3)大川市と諸富町からの予算の他に(4)賛助会員 の会費、(5)物品販売による売り上げなどにより賄われて いる。

また、この観光財団の設立の資本金には、大川市が財 団の基本財産として寄付寸るといら形でb)で述べた撤去 費用が活用されている ${ }^{69}$ 。この基本財産は設立当初から 預金され、有事の際は撤去費用として用いることとして いる ${ }^{66)}$ 。そして預金の利息を財団の運営や昇開橋の管理 に充てることで維持管理費用の一部を担保している ${ }^{47)}$ 。

また、観光財団龍氏へのヒアリングによると財団の設 立については「財団を設立したのは、1市1町に跨って
架かる昇開橋の管理を行いや寸くするための措置であ る」と述べられている。このことは、4. (2)d)で示したよ うに、整備費、運営費を大川市と諸富町で 2 分の 1 ずつ とする覚書を交わし、維持管理の財源の問題を保存決定 前に明確に取り決めていることからもわかる。

このように、維持管理費用は撤去費用を元手に観光財 団を設立することで確保することができたと考えられる。

\section{d）整備費用}

5. (2)において、昇開橋の保存には交通機能を維持する ことが必要であったことは述べた。また、a)で述べたよ うに、歩道橋として利用する際に、鉄道橋として利用さ れていた状態から、レールの撤去や床版の打設を行うた めの整備が必要であった。協議の当初はその資金を清算 事業団に要望していた ${ }^{70}$ 。しかし、最終的には、保存決 定後の 1993 (平成元) 年から 1995 (平成 3) 年に行われ た遊歩道整備事業は、新たに事業を立ち上げて行うこと で、撤去費用、維持管理費用とは別に、地域総合整備事 業債や宝くじ助成などにより別の財源を確保した ${ }^{71}$ 。こ れにより財団の資本金として大川市が負担した 3 億円を、 維持管理費用と将来的な撤去費用の財源に活用できたと 考えられる。

\section{6. 結論}

以上のことから、昇開橋の保存決定までには、佐賀線 廃止に伴い地元住民による保存運動がおこり、同様に、 地元自治体である大川市、諸富町が保存に向けて、住民 之協力し、周辺自治体や民間に援助を依頼し、昇開橋 保存のために積極的に要望や協議を行ったことで保存に 至ったことがわかった。

保存決定の要因は、昇開橋が地域シンボルとして認知 度が高く、それによって地元の商業地区住民によって保 存運動が起こり、また、地元自治体も昇開橋の観光資源 としての利用に向けて、保存に向けた活動を行ったこと が挙げられる。また、歩道橋として継続利用することが できたこと、そして、保存に必要な撤去費用、維持管理 費用、整備費用の財源を確保することが可能だったこと が保存決定の要因となった。

本研究は、一事例のみを対象としているため、他の保 存事例や保存に至らなかった事例についても同様の調査 を行い、比較検討することにより、保存の方策を検討す ることが今後の課題である。

\section{謝辞}

本研究を進めるにあたり、貴重なご意見、資料を頂き ました財団法人筑後川昇開橋観光財団理事長龍氏、若津 振興会加藤氏、佐賀市諸富支所、大川市、国土交通省、 文化庁、独立行政法人鉄道建設・運輸施設整備支援機構 の皆様に深く感謝致します。

\section{補注}


$※ 1$ 「図説 - 日本の近代化遺産」(北河大次郎, 後藤治編著, 河出 書房新社，2007，p.6）によれば、近代化遺産という語は、1990 年から文化庁と全国の文化財行政によって全国の近代化遺産 の状況を把握するための近代化遺産総合調査を行うにあたり、 文化庁が造語したもの。

※2 地域住民による手記

※3 乗客数（降客は除いた数）は筑後大川駅で 1959 年度 1103 人を ピークに、1964年度は 806 人、1969 年度は 705 人に減少している。

$※ 4$ 国鉄佐賀線存続期成会メンバー

$※ 5$ 国鉄所有時代の名称は筑後川橋梁で、現在は筑後川昇開橋と なっている。

$※ 6$ 大川市の線路跡買取費用は、国鉄との詳細な協議資料が無い ために、撤去費用として概算された金額、財団への寄付金の 金額が正確に一致しているかはわからない。そのため、文中 及び図-3における記述については、参考文献11)や新聞の記述 ヒアリング結果を元に約 3 億円で統一した。ただし、図 -4 中 における観光財団の基本財産（資本金）については、文献 47) より 351,578 千円と明らかになっている。

\section{参考文献}

1）文化遺産オンライン : http://bunka. nii. ac. jp/Index. do, 2009. 2.25

2）例えば, 福岡県教育委員会編 : 福岡県近代化遺産総合調査報 告書, 西日本文化協会, 1993

3）土木学会 : 日本近代土木遺産改訂版, 2005

4）例えば, 馬場俊介, 増田智彦, 岩村高正 : 中部 5 県の近代土 木遺産一道路隧道·砂防堰堤·発電堰堤の評価, 土木史研究, vol. 14, pp. 109-pp. 124, 1994

5）今尚之, 進藤義郎, 原口征人, 佐藤馨一：旧国鉄士幌線の 鉄道土木遺産とその保全活用について, 土木史研究, vol. 19, pp. 345-pp. 352， 1999

6）安田和樹・佐々木葉 : 近代土木遺産の保全・活用事業のプロ セスと効果に関する調査研究, 土木史研究講演集, vol.24, pp. 393-pp. 398, 2004

7）例えば, 鮫島茂: 佐賀線筑後川橋梁工事に就いて, 土木学会 誌, pp. 8, 20 巻 8 号, 1934

8）伊東孝：「可動橋一覧」の作成と近代可動橋の現在と評価, 土 木史研究，vol. 12，pp. 175-pp. 184，1992

9）筑後川昇開橋について, 財団法人筑後川昇開橋観光財団, 1996

10）筑後川昇開橋, 諸富町, p6, 2005

11）福岡日日新聞, 1935. 5.25

12）福岡県三濐郡小学校教育振興会編: 大川市誌, p. 1067, 1978

13）工事画報，6月号，p. 309，1935

14）鉄道博物館: http://www. railway-museum. jp/exhibition/103. html, 2009. 6. 25

15）坂本種芳 : 佐賀線筑後川橋梁可動装置の設計に就て, 土木学 会誌，p. 93-p. 103，1935.1

16）福岡県三溷都小学校教育振興会編 : 大川市誌, p. 1045, 1978

17）福岡県三瀦郡小学校教育振興会編: 大川市誌, p. 1050, 1978

18）筑後川昇開橋，諸富町，p17，2005

19）国鉄佐賀線存続期成会経過報告, 1987.6

20）国会会議録衆議院運輸委員会国鉄佐賀線の廃止反対に関する 陳情書（第一四一号），国会会議録衆議院運輸委員会 2 号， 1948. 12
21）法庫 : http://www. houko. com/00/01/S55/111. HTM, 2009. 7. 20

22）国鉄佐賀線存続期成会昭和 62 年度総会議案, p. 2, 1987.6.2

23）第 4 回特定地方特定交通対策協議会会議録, 1986.4.18

24）第 5 回特定地方特定交通対策協議会会議録, 1986.6.4

25）第6 回特定地方特定交通対策協議会会議録, 1987.1.2

26）第 7 回特定地方特定交通対策協議会会議録, 1987.2.25

27）国鉄佐賀線存続期成会昭和 62 年度総会議案, p. 2, 1987.6.2

28）佐賀線存続期成会幹事会資料, 1986.4.18

29）朝日新聞，1986.11.29

30）例えば西日本新聞， 1987.3.27

31）国鉄佐賀線存続期成会昭和 62 年度総会議案, p. 5, 1987.6.2

32）毎日新聞, 1987.2.25

33）昇開橋保存ついて打ち合わせ議事録, 大川市・諸富町, 1982.1.5

34）若津振興会設立総会資料, 1987.2.9

35）陳情書, 若津振興会，1987.2.24

36）昇開橋に関する市民からの投書写し，大川市，1987.3.6

37）国鉄佐賀線存続期成会昭和 62 年度総会議案, p. 1, 1987.6.2

38）筑後川昇開橋，諸富町，p2，2005

39）佐賀新聞， 1987.10.16

40）昇開橋の経費に関寸る覚書写し, 諸富町資料, 1992

41）筑後川昇開橋, 諸富町, p17, 2005

42）土地等譲渡契約書写し，日本国有鉄道清算事業団・大川市, 1992

43）筑後川昇開橋保存整備計画案, 1991.1

44）財団法人筑後川昇開橋観光財団リーフレット, 2007

45）財団法人筑後川昇開橋観光財団の設立について, 財団法人筑 後川昇開橋観光財団, 1995

46）財団法人筑後川昇開橋観光財団理事会資料, 財団法人筑後川 昇開橋観光財団, 1996

47）筑後川昇開橋観光財団 : 平成 19 年度収支計算書, 2007

48）文化庁答申， 1996.12

49）文化庁答申，2005.4

50）佐賀新聞， 1987.2.14

51）おおかわ文庫－大川風土記一，おお加わ文庫編集委員会， 1982. 12

52）例えば，佐賀新聞 1986.5.4 号では『諸富鉄橋』，文献 32）で は『国鉄昇開橋』と表記されている。

53）佐賀新聞 : 昇開橋存続に関するアンケート，1987.10.16

54）西日本新聞, 1987.3.27

55）佐賀新聞， 1987.6.6

56）大川都市レクゾーン計画, 若津振興会, 2007.6+1987. 12.21

57）佐賀新聞，1987.6.6

58）県民だより，1988.8.1

59）佐賀新聞 : 昇開橋存続に関するアンケート，1987.10.16

60）大川市観光リーフレット

61）朝日新聞, 1966.4.16

62）朝日新聞, 1976.5.31

63）朝日新聞, 1989. 7.24

64）朝日新聞, 1993.7.5

65）佐賀新聞 : 昇開橋存続に関するアンケート, 1987.10.16

66）佐賀線跡地及び周辺開発特別委員会記録, 大川市, 1990.7.31

67）まちづくり研究報告書, 産業経済部会, 1993

68）例えば、西日本新聞, 1992.7.7

69）昇開橋に関する河川占用許可権利譲渡承認申請書添付資料 $11,1992.4$

70）西日本新聞, 1991.11.9

71）財団法人筑後川昇開橋観光財団設立資料, 1998 


\section{近代化遺産橋梁の保存決定要因に関する研究 - 旧国鉄佐賀線・筑後川昇開橋を事例として -*}

榎本碧 ${ }^{* *} \cdot$ 高尾忠志 ${ }^{* * *} \cdot$ 樋口明彦

本研究は近代化遺産橋梁を対象とし、その保存決定の要因を明らかにすることを目的とした。

研究対象の筑後川昇開橋は、佐賀線の廃止に伴い撤去が計画され、地域住民や自治体が保存要望を提出する など保存運動が行われ、保存が決定した事例である。

昇開橋の保存決定の要因は、地域シンボルとして認知度が高く、それによって地元の商業地区住民によって 保存運動が起こり、また、地元自治体も昇開橋の観光資源としての利用に向けて、保存に向けた活動を行った ことが挙げられる。また、歩道橋として継続利用することができたこと、そして、保存に必要な撤去費用、維 持管理費用、整備費用の財源を確保することが可能だったことが保存決定の要因となった。

A Case Study on the Decision of Preservation of athe Chikugo River Lift Bridge as an Industrial Heritage Bridge* By Midori ENOMOTO** Tadashi TAKAO*** Akihiko HIGUCHI****

Chikugo River Lift Bridge is located between Fukuoka prefecture and Saga prefecture。 The bridge was built as a part of Saga train line in 1935. In 1987, the train line was listed with many other lines to be removed by Government. Immediately after the listing, the local citizens stood up to stop the demolition of the bridge. The campaign by the citizens moved the government in 1987 and the bridge was given to Okawa city and Saga city in 1992.

The purpose of this paper is to examine the process of the preservation campaign and currently applied preservation system. 